\title{
Medical management of ischemic stuttering priapism: a contemporary review of the literature
}

\author{
Helen R Levey ${ }^{1}$, Omer Kutlu ${ }^{2}$ and Trinity J Bivalacqua ${ }^{2}$ \\ Priapism is defined as a prolonged and persistent erection of the penis without sexual stimulation. This is a poorly understood disease \\ process with little information on the pathophysiology of this erectile disorder. Complications from this disorder are devastating due to \\ the irreversible erectile damage and resultant erectile dysfunction (ED). Stuttering priapism, though relatively rare, affects a high \\ prevalence of men with sickle-cell disease (SCD) and presents a challenging problem with guidelines for treatment lacking or resulting \\ in permanent ED. The mechanisms involved in the development of priapism in this cohort are poorly characterized; therefore, medical \\ management of priapism represents a therapeutic challenge to urologists. Additional research is warranted, so we can effectively target \\ treatments for these patients with prevention as the goal. This review gives an introduction to stuttering priapism and its clinical \\ significance, specifically with regards to the patient with SCD. Additionally, the proposed mechanisms behind its pathophysiology and \\ a summary of the current and future targets for medical management are discussed.
}

Asian Journal of Andrology (2012) 14, 156-163; doi:10.1038/aja.2011.114; published online 7 November 2011

Keywords: erectile dysfunction; ischemic priapism; medical management; recurrent priapism; sickle cell disease; stuttering priapism; therapy; treatment

\section{INTRODUCTION}

Priapism represents one of the greatest challenges in therapeutic management among erectile disorders. ${ }^{1}$ Priapism is defined as a prolonged and persistent penile erection lasting greater than $4 \mathrm{~h}$, unassociated with sexual interest or stimulation. ${ }^{2,3}$ It constitutes a true disorder of erection physiology, associated with risks of structural damage to the penis and permanent erectile dysfunction (ED). Priapism has been divided into three main categories: ischemic, non-ischemic and stuttering priapism. ${ }^{2}$ This review will focus on stuttering priapism, a distinct category of recurrent ischemic priapism with an emphasis on patients with sickle-cell disease (SCD).

Ischemic priapism, also termed veno-occlusive or low flow priapism, is a persistent erection marked by rigidity of the corpora cavernosa and little or no cavernous arterial inflow. ${ }^{2}$ The etiology of ischemic priapism is predominated by SCD. ${ }^{4}$ Stuttering priapism, also termed intermittent or recurrent priapism, is characterized by recurring episodes of ischemic priapism. The recurrent episodes may increase in frequency and or duration, potentially developing into major episodes of ischemic priapism that necessitate emergent measures. ${ }^{2}$ These patients having acute episodes of stuttering priapism may develop ischemia and pain with erections lasting greater than $4 \mathrm{~h}$ and will need treatment following the guidelines for ischemic priapism. Conversely, any person who has suffered from an acute ischemic priapic event may be at risk for developing stuttering episodes. Patients with chronic stuttering episodes, defined as those having erections lasting less than $4 \mathrm{~h}$ in duration, will benefit the most from medical therapy aimed at prevention.

\section{EPIDEMIOLOGY OF PRIAPISM AND PATIENT POPULATIONS AT RISK}

While priapism is a rare disorder in general, specific patient populations, namely those with SCD, are affected with greater frequencies and comprise a major risk cohort for the development of priapism. ${ }^{3}$ In the United States alone, over 70000 individuals live with SCD, and worldwide, estimates are as high as $20-25$ million. ${ }^{5}$ The lifetime probability for the development of clinically significant priapism is as high as $42 \%$ in men with SCD, and the rate of resultant ED exceeds $30 \%{ }^{3,6-8}$ Typically, there is a bimodal peak of incidence between 5 and 10 years in children and $20-50$ years in adults. ${ }^{9}$ By the time most men with SCD reach their twenties, greater than $75 \%$ of them will have already experienced their first episode of priapism, with the mean age of occurrence between 12 and 15 years old. ${ }^{6,8,10,11}$ SCD is the most common etiology of priapism in childhood accounting for $63 \%$ of cases and is the primary etiology of ischemic priapism in $23 \%$ of adult cases. ${ }^{12}$ The fact that SCD populations are affected to a greater degree by priapism emphasizes the public health significance of this problem and, more importantly, the need for education and preventive efforts in addressing solutions.

While priapism has been recognized since 1934 as a serious complication of SCD, a study in 2008 by Bennett and Mulhall, showed that only $5 \%$ of men with SCD had ever been counseled or were made aware that priapism was a complication of SCD, while greater than $70 \%$ of these men admitted to having had a prior episode of stuttering priapism. ${ }^{13,14}$ These findings have been conveyed in other studies as well indicating the significance for education and prompt

${ }^{1}$ The Arthur Smith Institute for Urology, North Shore - Long Island Jewish Health System, New Hyde Park, NY 11010, USA and ${ }^{2}$ The James Buchanan Brady Urological Institute, Department of Urology, Johns Hopkins Hospital, Baltimore, MD 21287, USA

Correspondence: Dr HR Levey (Helen.Levey@gmail.com)

Received: 22 April 2011; Revised: 10 June 2011; Accepted: 15 June 2011; Published online: 7 November 2011 
treatment. ${ }^{6,8}$ Delays in treatment and repetitive episodes of stuttering priapism lead to cellular, molecular and morphological changes in the corpus cavernosum, which over time result in tissue injury that can accumulate developing into permanent ED. ${ }^{15,16}$ In addition to the profound decrement in quality of life that results from having permanent ED, SCD patients that experience priapism have a fivefold greater risk of developing pulmonary hypertension, and thus, the comorbidities which follow. ${ }^{4,17,18}$

With the relatively young age of initial onset and the devastating irreversible consequences of priapism, a proactive preventive approach to treatment is imperative. Current first-line therapies for acute ischemic priapism consisting of reactive surgical blood draining procedures are often unable to preserve erectile function, thus urging the development of treatments that can be offered preventatively, particularly to those who are predisposed to recurrences. It is critical for urologists to understand the clinical presentation and management, as well as the molecular science behind priapism in order to formulate therapeutic options which not only treat the acute episodes but work towards prevention of stuttering priapism, in addition to educating their patients prone to these recurrences about priapism.

\section{PATHOPHYSIOLOGY AND MECHANISMS OF DISEASE}

Since the development of a transgenic sickle-cell mouse model in 2009 to study the pathophysiology of priapism, several studies have emerged proposing novel mechanisms for the occurrence of stuttering priapism, specifically with relation to patients with SCD.

The conventional understanding is that adverse hematogenous factors, venous congestion and enhanced blood viscosity serve as the pathophysiologic basis for priapism associated with SCD (Figure 1). ${ }^{4,6,19,20}$ It is understood that normal erection decreases oxygen tension in the corpora cavernosa, predisposing erythrocytes to sickle. ${ }^{4,21}$ The sickled erythrocytes induce venous stasis and congestion, obstructing the penile vessels leading to priapism. ${ }^{4,6,21}$ This results in damage to the corporal smooth muscle and vascular endothelium creating an inflammatory reaction resulting in penile fibrosis and subsequent ED and impotence. ${ }^{3,4,6,22}$

While the aforementioned mechanism may contribute to SCDassociated priapism, this conventional understanding fails to explain many divergent presentations of priapism. Recent advances in the field are now suggesting that factors involved in pathways affecting inflammation, cellular adhesion, NO metabolism, vascular reactivity and coagulation may all play a role in the pathophysiology of SCDassociated stuttering priapism. ${ }^{4,23,24}$ Therefore, complex interactions between sickle reticulocytes, neutrophils, monocytes and the endothelium may provide new targets for therapy. The ultimate goal of the treating urologist is to prevent stuttering priapism through the use of pharmacotherapies that address the underlying pathophysiology of the disease.

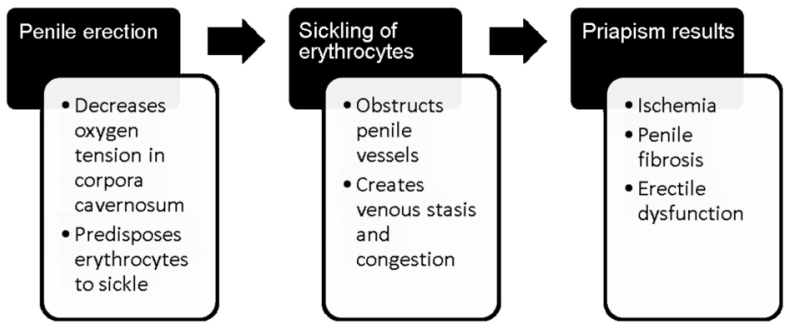

Figure 1 Conventional mechanism of SCD-associated priapism. SCD, sickle-cell disease.

\section{MEDICAL MANAGEMENT}

The mechanisms involved in the development of priapism are poorly characterized; therefore, the current medical management is oftentimes ineffective. Table $\mathbf{1}$ is a summary of current and future medical management options for the treatment and more importantly, prevention of stuttering priapism.

\section{Pharmacotherapy}

It is important to note that first-line therapy for patients with episodes of acute ischemic priapism evolving from stuttering priapism, remains the same as for ischemic priapism: aspiration/irrigation in combination with intracavernous $\alpha$-agonist injection therapy. If a patient has an acute priapic event and associated prolonged erection for $>4 \mathrm{~h}$ with significant pain, then this represents a true compartment syndrome and should be addressed immediately. For priapism specifically related to SCD, medical therapies such as alkalinization and exchange transfusion may be performed, after the initial first-line therapy has been initiated. ${ }^{1-4,8,15}$ Current American Urological Association (AUA) and International Consultation on Sexual Medicine guidelines do not recommend these therapies for primary treatment as alkalinization works to reverse the acidic environment hemolysis creates and exchange transfusions serve to increase the reduced hemoglobin levels in the body to greater than $10 \%$; thus the penile compartment syndrome must be decompressed before considering exchange transfusion in priapism for SCD patients

\section{Hormonal therapy}

The use of hormonal therapy for prevention of stuttering priapism has been a successful medical management option for some patients. ${ }^{1-4,25-32}$ Systemic hormonal therapy works by exploiting the known regulators of male sexual function by targeting the hormonal axis, acting to suppress the androgenic effects on penile erection. ${ }^{4}$ Caution is strongly advised in using hormonal treatments for prepubertal or adolescent men who have not reached sexual maturation and or in those desiring children, as side effects often result in castrate levels of testosterone creating a contraceptive effect, interfere with closure of the epiphyseal plates and have significant impairments on sexual function. ${ }^{2,21}$ For these men, hormonal agents are not recommended. Instead, proper instruction on the use of at-home intracavernosal self-injection therapy with sympathomimetics may be considered, ensuring that patients are first instructed on the duration of erection prompting treatment, correct injection site, dosing and potential side effects. ${ }^{2,33-36}$ As with all medical decisions, the choice of hormonal therapy should be decided upon by both the treating physician and the patient, following an informed discussion reviewing all available therapeutic options, their risks and benefits.

GnRH agonists. Several case reports have used GnRH agonists, such as goserelin acetate and leuprolide acetate in the management of stuttering priapism with or without concurrent as-needed patient selfadministration of intracavernous $\alpha$-adrenergic injections. ${ }^{27,31} \mathrm{GnRH}$ agonists work by the process of receptor downregulation, thereby suppressing luteinizing hormone (LH). Initially, GnRH agonists stimulate LH production, and create a rise in testosterone levels. After a few weeks, desensitization of the LH-releasing hormone receptor ensues and production of both $\mathrm{LH}$ and testosterone decrease to castrate levels. While one case study reported no problems with libido or erectile function on GnRH therapy, another study by Levine and Guss using leuprolide acetate reported that while libido was maintained, erectile function was lost with total serum testosterone levels 


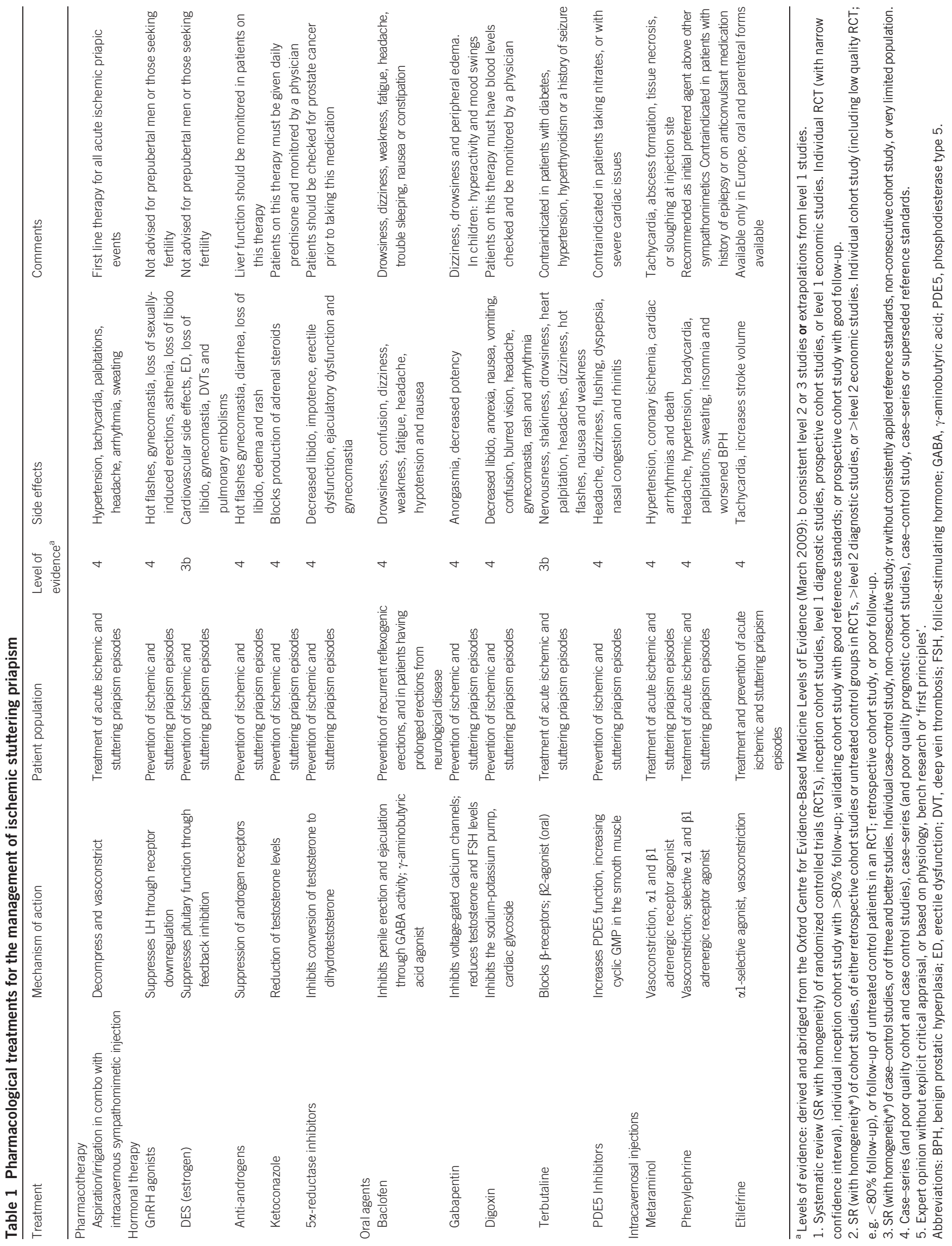


less than $20 \mathrm{ng} \mathrm{dl}^{-1}$ after treatment. ${ }^{31}$ Side effects reported with the use of GnRH agonists include hot flashes, gynecomastia, loss of sexually induced erections, asthenia and loss of libido. ${ }^{29,31,37}$

Estrogen. Only one randomized, placebo-controlled trial has been conducted using diethylstilbestrol or DES, a synthetic estrogen, to treat patients with stuttering priapism. In this study, DES therapy caused termination of the stuttering episode in all patients; however, in more than $50 \%$ of the patients (five out of nine) stuttering priapism recurred following termination of treatment. ${ }^{38,39}$ Several case reports have suggested that long-term estrogen therapy is not recommended due to potential cardiovascular side effects and development of ED, decreased libido and gynecomastia. ${ }^{4,26,27,30}$ In addition, DES has been associated with the development of deep venous thromboses and pulmonary embolisms. ${ }^{39}$ Therefore, while effective in the short term, DES therapy is not used in clinical practice to treat stuttering priapism.

Anti-androgens. Anti-androgens, such as flutamide, bicalutamide and chlormadinone, cause direct suppression of penile androgen receptors. These agents have been shown to be effective in relieving stuttering priapism without the loss of libido that is commonly seen with GnRH agonists and estrogen therapy. ${ }^{26,29,36}$ In a study by Dahm et al., ${ }^{29}$ three men with SCD and refractory priapism were placed on $50 \mathrm{mg}$ daily bicalutamide therapy and all had significant improvements with their refractory priapism. Yamashita et al. ${ }^{26}$ also found that $100 \mathrm{mg}$ chlormadinone acetate alleviated priapism. In their study, however, the patient complained of ED due to low levels of testosterone and subsequently elected to discontinue treatment. In another case report, Costabile described the successful treatment of stuttering priapism with $125-250 \mathrm{mg}$ oral flutamide therapy three times a day. ${ }^{28}$ In addition to these promising reports, anti-androgens are not associated with the temporary rise in testosterone commonly seen in $\mathrm{GnRH}$ analogues, and their side effect profile is considerably more favorable than that of DES. Common side effects of anti-androgens include hot flashes, gynecomastia, diarrhea, loss of libido and ED with higher doses. ${ }^{28,29,31,37,40,41}$ Flutamide specifically may cause edema or rash. Liver function should be monitored in patients on this therapy. Although anti-androgens have been shown to be effective in small case reports, this treatment does not represent a mechanisms-based pharmacotherapy and further investigation of anti-androgens in large prospective randomized trials is needed to assess their efficacy and durability for use in long-term treatment of stuttering priapism.

Ketoconazole. Ketoconazole is an antifungal agent that interferes with the synthesis of ergosterole, the main constituent in fungal cell membranes. ${ }^{41}$ In addition to its antifungal action, ketoconazole has a resultant side effect that creates a reduction in testosterone levels which has been observed in the treatment of metastatic prostate cancer, preventing postoperative erections and various other medical conditions. ${ }^{41-43}$ This decrease in testosterone is the reasoning behind the use of ketoconazole in the treatment of recurrent priapism. All patients receiving ketoconazole should be monitored by a physician and given daily prednisone due to ketoconazole's blocking action on the production of adrenal steroids.

In 2009, Abern and Levine treated eight patients with recurrent stuttering priapism using ketoconazole and prednisone dose titrated until patient testosterone levels were reduced to $200 \mathrm{ng} \mathrm{dl}^{-1} \cdot{ }^{25}$ After a mean follow-up of 1.5 years, they reported that ketoconazole with prednisone was well tolerated in these patients, cost-effective and successfully prevented stuttering priapism while retaining sexual function. ${ }^{25}$ While potentially effective and promising for use in prepubertal men and those desiring fertility, these results need to be extended into randomized controlled trials before gaining widespread use.

$5 \alpha$-reductase inhibitors. Finasteride, a $5 \alpha$-reductase inhibitor, blocks the conversion of testosterone to dihydrotestosterone, and has been used to treat idiopathic and stuttering priapism. In a study by RachidFilho et al., ${ }^{40}$ finasteride was administered for 120 days in tapering doses to 35 men with recurrent priapism secondary to SCD. Prior to beginning finasteride, the mean episodes of priapism per patient were 22.7. Following 4 months of treatment, the mean number of priapic events was reduced to 2.1 with only six men experiencing gynecomastia. The optimal outcomes were found using finasteride in 3 and $5 \mathrm{mg}$ per day doses. Future large scale studies are needed to further corroborate these findings and to assess fertility and side effects using finasteride in young populations.

Of the systemic therapies that have been proposed and will be discussed further in this review for the prevention of priapism, hormonal agents, such as GnRH agonists or anti-androgens have been the most consistent successful treatments documented and are therefore, recommended as primary treatments for the management of stuttering priapism. ${ }^{2,36}$

\section{Other oral agents}

Baclofen. Baclofen, a $\gamma$-aminobutyric acid derivative, is a muscle relaxant and antimuscle spasm agent shown to be beneficial in a single study in patients suffering from recurrent reflexogenic erections. ${ }^{4}$ Both rat and human studies have demonstrated that baclofen inhibits penile erection and ejaculation through its $\gamma$-aminobutyric acid activity. ${ }^{44-46}$ These recurrent erections are associated with muscle spasticity in men with spinal cord lesions and neurologic disease. While the characteristics and pathophysiology of this form of priapism are still being studied, several reports have described a beneficial response with the use of intrathecal baclofen. ${ }^{47-49}$ These studies suggest that oral baclofen therapy fails to elicit the same response in patients as intrathecal baclofen dosing. ${ }^{47,48}$ The current literature neglects to categorize this type of priapism as ischemic or non-ischemic, so additional studies are needed to assess the congruence or lack thereof between recurrent reflexogenic erections and ischemic stuttering episodes. ${ }^{4,32}$ In clinical practice, baclofen is not used to treat stuttering priapism but often used in patients having prolonged erections from neurological disease or injury. These types of patients include those presenting with spinal cord injury, neurogenic or distributive shock, degenerative spinal canal stenosis and spondylolisthesis. On admission symptoms will be similar to ischemic priapism with painful prolonged erections, but may include intermittent neurogenic claudication, sensory deficits, involuntary erections and other neurological sequela. ${ }^{50}$

Gabapentin. Gabapentin is a widely used analgesic and antiepileptic agent with anticonvulsant, antinociceptive and anxiolytic properties. ${ }^{51}$ The rationale behind the treatment of priapism with gabapentin arose from reported sexual dysfunctions such as anorgasmia and decreased potency experienced by patients taking gabapentin. While the exact mechanism of action remains unknown, studies on rats have eluded to gabapentin's therapeutic effect in the management of priapism. ${ }^{41,51,52}$ These studies demonstrated that gabapentin selectively inhibits calcium influx by inhibiting voltage-gated calcium channels, thereby attenuating synaptic transmission. ${ }^{41}$ While the molecular targets of gabapentin remain unknown, inhibition of 
calcium efflux from smooth muscle cells in the corpora, with consequent inhibition of smooth muscle relaxation, serves to explain the therapeutic response seen in gabapentin users. ${ }^{41}$ Another potential mechanism may be gabapentin's ability to reduce testosterone and follicle-stimulating hormone levels, as seen in a study by Daoud et al. ${ }^{53}$

In a small study by Perimenis et al., ${ }^{51}$ three men with refractory priapism were treated with oral gabapentin. Each man responded to treatment within $48 \mathrm{~h}$, and was sent home with varying doses of gabapentin to continue daily. Two men no longer experienced priapism following 16 and 24 months of treatment respectively, while one patient had recurrence of priapism at 6 months following discontinuation of treatment. Upon re-initiation of treatment, his priapism was resolved for an additional 9 months while taking gabapentin. ${ }^{51}$ While gabapentin appears to have a beneficial effect on the treatment of priapism, larger studies are needed to examine the reproducibility of these effects, its clinical efficacy, and mechanism of action.

Digoxin. Digoxin is an inhibitor of the sodium-potassium pump, most commonly used in patients with congestive heart disease. Digoxin inhibits the smooth muscle membrane sodium-potassium adenosine triphosphatase, which reduces the sodium concentration gradient and prevents efflux of $\mathrm{Ca}^{2+}$ from the smooth muscle cell thereby increasing intracellular $\mathrm{Ca}^{2+}$ levels. ${ }^{41,54-56}$ This regulates smooth muscle tone leading to penile detumescence. A small in vivo double-blind placebo-controlled study involving six patients using doses of $0.25-0.5 \mathrm{mg}$ per day of digoxin, reported no significant effect on patient plasma levels of testosterone, estrogen or LH, despite subjective assessments indicating a decrease in sexual desire and excitement with a concurrent reduction in penile rigidity. ${ }^{55}$ This same group performed an in vitro study to examine these findings and reported that digoxin impaired NO-mediated smooth muscle relaxation in human corpus cavernosum smooth muscle. ${ }^{55}$ Further, a multicenter study investigating the use of digoxin in idiopathic stuttering priapism found that at maintenance doses of $0.25-0.5 \mathrm{mg}$ daily, patients reported fewer hospital visits and better quality of life with no adverse effects. ${ }^{57}$ While there have been in vivo and in vitro studies looking at the effects of digoxin for treating priapism, the routine use of digoxin as a first-line management option is not universal, as digoxin must be closely monitored in patients due to its side effect profile and necessary blood level monitoring.

Terbutaline. Beta-agonists, such as terbutaline, act as vasodilators by blocking beta receptors, resulting in smooth muscle relaxation of the vasculature. In SCD patients, this allows oxygenated arterial blood to enter the cavernosa, washing out the stagnant, already damaged sickle cells. Therefore, terbutaline may serve as an emerging agent in the prevention of SCD-associated stuttering priapism.

Terbutaline has been demonstrated in in vivo and in vitro studies to exert a preferential effect on $\beta$-2-adrenergic receptors. ${ }^{41,52,58-60}$ The use of oral terbutaline was reported in a case study of an 11-year-old boy with erections lasting over $6 \mathrm{~h} .{ }^{61}$ After detumescence was achieved, the boy was given $3 \mathrm{mg}$ oral terbutaline and observed for $12 \mathrm{~h}$. He was discharged home with a protocol to take $1.5 \mathrm{mg}$ oral terbutaline three times daily for 1 week. At 6-month follow-up, no further recurrences were reported. ${ }^{61}$ In a placebo-controlled trial of 75 patients utilizing terbutaline and pseudoephedrine in the management of PGE1induced priapism, $36 \%$ of patients receiving terbutaline achieved detumescence, while $28 \%$ of patients receiving pseudoephedrine and only $12 \%$ of the placebo group $(P<0.05)$ achieved detumescence. ${ }^{62}$ In another study by Shantha et al., ${ }^{63}$ six patients were treated with oral terbutaline for persistent erection. Five patients had pharmacologically-induced priapism, while one patient was taking antipsychotic medications. In this patient, following treatment with a shunt procedure, priapism recurred. He was given $0.5 \mathrm{mg}$ terbutaline subcutaneously every $4 \mathrm{~h}$ for the next $48 \mathrm{~h} .{ }^{63}$ Full resolution of priapism occurred at $24 \mathrm{~h}$. The patient returned 1.5 months later with recurrent priapism and again received $0.25 \mathrm{mg}$ subcutaneous terbutaline every 6 h. Within $30 \mathrm{~min}$ of the first injection, the penis softened and at $24 \mathrm{~h}$, priapism was completely resolved. ${ }^{63}$ The only adverse effect reported was bilateral fibrosis of the distal corpora. However, this likely resulted from the initial shunt procedure. ${ }^{63}$ While this and other studies have demonstrated terbutaline as an effective agent for initial management of pharmacologically induced priapism, there have been limited studies evaluating its effectiveness for specifically stuttering priapism. In addition, terbutaline has limited use, as it is contraindicated in patients with diabetes, hypertension, hyperthyroidism or in patients with a history of seizure. ${ }^{41}$

Phosphodiesterase type 5 (PDE5) inhibitors. Recent studies have shown recurrent priapism to be related to a defective PDE5 regulatory function in the penis, resulting from altered nitric oxide and cyclic guanosine monophosphate signaling mechanisms which control erectile function (Figure 2). ${ }^{4,8,15,22,64}$ A leading proposal in this regard, is that NO becomes dysfunctional in association with underlying disease states. While oral PDE5 inhibitors such as sildenafil or tadalafil, are commonly used as medical treatment for ED, exerting erectogenic effects, scientific evidence has shown they have a paradoxical effect in alleviating stuttering priapism. ${ }^{23,64-68}$ PDE5 inhibitors work under the theory that PDE5 becomes downregulated in the penis, as a result of altered signaling of the NO pathway. This mechanism allows cyclic guanosine monophosphate to build up in the corpora cavernosa, and therefore cyclic guanosine monophosphate cannot be degraded due to lack of PDE5 function; thus, prolonged corporal smooth muscle relaxation and associated priapism occur. ${ }^{1-4,22,64-68}$ In a small case series, Burnett and colleagues ${ }^{67}$ have shown that daily PDE5 inhibitor therapy reduces ischemic priapism episodes in men with stuttering priapism. Long-term therapy with PDE5 inhibitors alleviated priapism in men with idiopathic priapism as well as SCD-associated priapism without affecting their normal erectile capacity. ${ }^{65,68}$ In these studies, the initial dose of sildenafil citrate was $25 \mathrm{mg}$ oral daily with escalation up to $50 \mathrm{mg}$ daily, and doses of tadalafil at 5-10 mg three times a week with fair success results. None of the patients reported any adverse events associated with PDE5 therapy and only one patient did not respond to treatment. This patient had SCD-associated

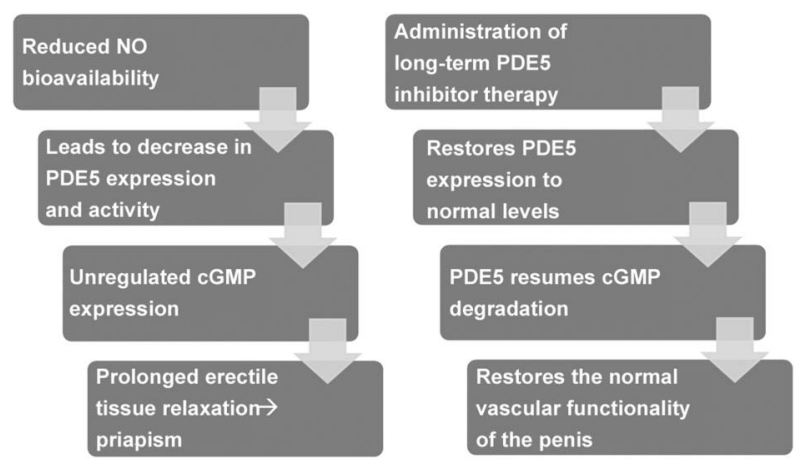

Figure 2 Proposed mechanism of SCD-associated priapism and management with PDE5 inhibitor therapy. PDE5, phosphodiesterase type 5; SCD, sickle-cell disease. 
priapism with a history of severe recurrent episodes. ${ }^{65}$ The findings in this study are encouraging, and suggest that treatment may be most useful for patients with mild or moderate disease. PDE5 inhibitors should be started in patients under conditions of complete penile flaccidity and not during a recurrent/stuttering episode. Efficacy is usually seen within 2-4 weeks of dosing. ${ }^{4}$ Intracavernosal self-injection of sympathomimetics may be used in the interim.

Current use of PDE5 inhibitors for treatment of stuttering ischemic priapism is contraindicated by the packaging labels and therefore considered investigational at present time. ${ }^{2}$ However, most treatment options available today fail to prevent episodes of priapism and their pathological consequences. It is here that PDE5 inhibitors offer promising new treatment possibilities for the prevention of stuttering priapism in this patient population. ${ }^{22,65-68}$ Consequently, multicenter, randomized, placebo-controlled trials are under way to further evaluate the potential use and benefit of PDE5 inhibitors for the treatment of stuttering priapism.

\section{Intracavernosal injections}

Sympathetic amines. The primary goal of medical therapy for ischemic or stuttering priapism is to relieve the pain and decompress the corporal bodies, thus reducing ischemia and the risk of tissue necrosis and injury. ${ }^{2,4,15,32}$ Some men initiated on systemic therapies for stuttering ischemic priapism may not see therapeutic effects immediately and may require intracavernous self-injections at home with sympathomimetic agents such as phenylephrine on an interim basis until ischemic priapism has been alleviated. ${ }^{32,65,67}$ Sympathomimetic agents are applied because of their contractile effects which may facilitate detumescence. ${ }^{1,2}$ All patients should be monitored for potential side effects resulting from the use of $\alpha$-agonists and entry into the systemic circulation. ${ }^{69}$ It is important to note that while the administration of sympathomimetics to treat acute priapism attacks have been used since 1986, none of these commonly used medications are approved under the Food and Drug Administration for the treatment of priapism, despite their reported beneficial effects. ${ }^{69,70}$ Below is a list of some commonly used sympathomimetic agents and studies supporting their use in the treatment of stuttering priapism.

Metaraminol. Metaraminol is a long-acting potent sympathomimetic amine whose vasoconstrictive properties are considered safer than epinephrine; however, common side effects may include hypertension, coronary ischemia, cardiac arrhythmias and death. ${ }^{41,69}$ In a single-case study, a sickle-cell trait carrying patient was successfully treated for stuttering priapism by injecting once weekly $5-10 \mathrm{mg}$ metaraminol. Complete detumescence was reported within 3-10 min following the injection. ${ }^{69}$

Phenylephrine. In 2001, Ralph et al. ${ }^{71}$ reported the use of a drug delivery implantation device that allowed for self-administration of intracavernosal phenylephrine for a patient with painful stuttering priapism. Through a lateral penoscrotal incision, the drug delivery implant was placed with the cannula inserted into the corpus cavernosum and the reservoir placed in a dependent position in the scrotum. After an initial titration period, the reservoir was filled with a 50-mg phenylephrine solution $\left(10 \mathrm{mg} \mathrm{ml}^{-1}\right)$ diluted with normal saline to a volume of $8 \mathrm{ml}$. One squeeze delivered $0.13-\mathrm{ml}$ phenylephrine solution into the corpus cavernosum. The patient successfully used this device for 4 months alleviating his prolonged painful erections. ${ }^{71}$
AUA guidelines are a set of recommendations for medical practitioners in the care of patients, based on review of current literature, clinical experience and expert opinion. While they serve as an expert guideline, they do not represent a fixed set of rules or a legal standard of care. As per AUA guidelines, phenylephrine is the preferred drug for intracavernosal injection therapy to alleviate acute ischemic priapism arising from stuttering priapism. Phenylephrine is recommended as it minimizes the risk of cardiovascular side effects compared with other sympathomimetic agents having $\beta$-adrenergic activity. ${ }^{1-3}$ For adult patients, the recommended dose of phenylephrine is a diluted 100$500 \mu \mathrm{g}$ per $\mathrm{ml}$ concentration, given in $1 \mathrm{ml}$ injections administered every $3-5$ min for approximately $1 \mathrm{~h}$ until detumescence occurs. If an erection persists after $1 \mathrm{~h}$, then treatment is considered unsuccessful. Children and patients with cardiovascular disease should receive lower concentrations in smaller volumes. Patients should be observed for resultant side effects such as acute hypertension, headache, reflex bradycardia, tachycardia, palpitations and cardiac arrhythmias during phenylephrine administration. Blood pressure and electrocardiogram monitoring are recommended in high risk patients.

Etilefrin. Another sympathomimetic, etilefrine, is an $\alpha 1$-selective agonist that has been shown to have fewer cardiovascular effects than other agents when used intracavernosally for the management of acute priapic episodes. ${ }^{34,35,41,72}$ A case study by Teloken et al. ${ }^{72}$ reported a 27-year-old man who presented with a 1-year history of idiopathic stuttering priapism occurring 3-4 times per week, who had failed initial treatment with oral terbutaline. The patient was started on a self-injection protocol, consisting of injecting $5 \mathrm{mg}$ etilefrine intracavernosally $1 \mathrm{~h}$ after spontaneous erections and repeating the dose every 15 min until detumescence was achieved. ${ }^{72}$ At follow-up, the patient reported having used etilefrine self-injections successfully for 10 years with good efficacy, libido and preservation of erectile function. ${ }^{72}$ Other studies have supported etilefrine's safety and efficacy for the treatment of priapism and its convenience is further enhanced by the availability of both an oral and parenteral formula. ${ }^{34,35}$

While self-injection protocols allow for the quick management of acute priapic episodes and decrease the chance of corporeal damage, the AUA recommends that intracavernosal self-injection of sympathomimetic amines should not be considered preferred treatment options over systemic therapies. ${ }^{2,35}$ This is due in large part to the fact that priapism in such cases is merely being treated rather than prevented and the potential for adverse systemic effects that exists with administration of these medications. ${ }^{2}$ Although not available in the United States, etilefrine is widely available in Europe. Other oral agents, such as ephedrine and pseudoephedrine, can be used in the States with similar success.

\section{Future targets: molecular mechanisms}

Opiorphins. Several groups have been looking at the molecular mechanisms that result in priapism in order to gain a better understanding of the disease and to identify targets useful for the development of pharmacotherapies to prevent stuttering priapism. . $3,24,41,64,73$ One exciting area of research involves the study of opiorphins. Opiorphins are a newly characterized class of peptides that act as potent endogenous neutral endopeptidase inhibitors. ${ }^{73}$ Recent reports have suggested that they play an important role in erectile physiology, and in sickle-cell mice, there is increased expression of the mouse opiorphin homologue in corporal tissue compared to wild-type mice. ${ }^{73}$ Plasmids expressing genes encoding for opiorphins, were intracorporally injected into retired breeder rats and following 
intracavernous injection, the breeder rats expressed a priapic-like condition. Analysis of these rats demonstrated that enzymes in the polyamine synthesis pathway were notably upregulated in these rats as compared to controls. ${ }^{73}$ Further, when inhibitors of the polyamine synthesis pathway were given to breeder rats prior to injection with these plasmids, it prevented the occurrence of experimental priapism. ${ }^{73}$ These results have suggested that upregulation of enzymes in the polyamine synthetic pathway may play a role in the development of priapism and thus represent future targets for the prevention of priapism. ${ }^{73}$

Adenosine. Adenosine is a signaling nucleoside that shares multiple features with NO; both are potent vasodilators, induce cyclic nucleotide second messengers and both affect penile erection. ${ }^{74-78}$ Recent studies in both animals and humans have shown that intracavernous injection of adenosine results in tumescence and penile erection, providing evidence that excess adenosine may contribute to priapism. ${ }^{74-76}$ Theophylline, an adenosine receptor antagonist, has consequently been shown to inhibit these adenosine-induced erections. ${ }^{74,79}$ These results suggest the possibility that another signaling pathway may represent a potential target for the future prevention and treatment of priapism.

\section{PERSPECTIVES}

Some of the treatments highlighted in this review are historical and no longer used in clinical practice. Additionally, limited outcomes data for many of the aforementioned treatments preclude strong recommendations for their support at this time. Currently, among the many systemic therapies that have been proposed for the prevention of stuttering priapism; hormonal agents have been the most consistent pharmacotherapy documented. ${ }^{2,36}$ Therefore, hormonal therapies, consisting of trials of $\mathrm{GnRH}$ agonists or androgen receptor antagonists, are supported as a primary recommendation and are recommended for use in the management of stuttering priapism. ${ }^{2,36}$ They are not, however, recommended for use in prepubertal men or those desiring fertility. Additionally, androgen deprivation does not have a pathophysiological basis and therefore, as clinician scientists we need to pursue the true pathophysiology of this disorder. For prepubertal men and those desiring fertility, self-administration of intracavernosal phenylephrine, is the most supported therapeutic option in the literature that would not interfere with reproduction or development. However, this does not serve to prevent priapism, only to treat it. The use of a drug delivery implantation device as described by Ralph et al. ${ }^{71}$ for administration of intracavernosal phenylephrine during stuttering events may provide relief from associated fibrosis resulting from multiple intracavernous self-injections in these patients and those prone to recurrent episodes. Further, a closer look into PDE5 inhibitor and ketoconazole therapy with concurrent prednisone administration may provide therapeutic control of stuttering episodes in prepubertal men or those desiring fertility without the resultant castration levels that commonly follow systemic hormonal therapies. ${ }^{25}$

While Abern and Levine's conclusions ${ }^{25}$ are potentially effective, and promising for use in these men, their results need to be extended into randomized controlled trials before gaining widespread use. ${ }^{25}$

An emerging and successful new therapy is the use of PDE5 inhibitors for the preventative treatment of stuttering episodes. ${ }^{4,64-68}$ PDE5 inhibitors may be used initially or in conjunction with concomitant administration of intracavernosal phenylephrine injections to treat acute episodes of priapism before PDE5 inhibitor therapy has taken full effect. Research is encouraging in this avenue and suggests PDE5 inhibitors as useful preventative therapy for mild-to-moderate cases of stuttering priapism with minimal side effects, commonly seen with other systemic therapies. ${ }^{67,68}$ Larger trials are currently underway for the use of PDE5 inhibitors in the management of stuttering ischemic priapism; however, its use is currently contraindicated by the packaging labels and therefore, considered investigational at present time. PDE5 inhibitor therapy is the first pharmacotherapy which targets the true molecular biology of priapism. ${ }^{22,23,64-68}$ While premature in its efforts to translate bench science to the clinic, novel discoveries in basic science research delving into opiorphins and adenosine as signaling pathways that may play a role in the development of stuttering ischemic priapism, represent exciting potential targets for future therapies directed at the prevention and thus treatment of priapism. ${ }^{73,74}$ While further research is needed to evaluate the safety and efficacy of systemic therapies for the prevention of stuttering ischemic priapism, a greater understanding of the pathophysiology involved in the mechanisms behind SCDassociated priapism, will continue to pave the way for novel emerging therapies to be developed focusing on prevention as the goal.

\section{CONCLUSION}

At present, there is no good medical management for the treatment of stuttering ischemic priapism, as most therapies fail to prevent the underlying cause, and focus solely on acute management of stuttering episodes. In current literature, there is no level 1 or 2 evidence to support any of the current pharmacotherapies for treatment and further research in thoughtful controlled clinical trials is needed before strong recommendations may be concluded. Unfortunately, this is difficult due to the rare nature of this condition. However, further research into the basic science behind priapism and recent published series using anti-androgens, androgen deprivation therapy and PDE5 inhibitors will highlight additional treatments that will likely be more effective, with prevention as the goal.

\section{COMPETING FINANCIAL INTERESTS}

Helen R. Levey, Omer Kutlu and Trinity J. Bivalacqua declare that they have no competing financial interests.

1 Berger R, Billups K, Brock G, Broderick GA, Dhabuwala CB, et al. Report of the American Foundation for Urological Disease (AFUD) thought leader panel for evaluation and treatment of priapism. Int J Impot Res 2001; 13(Suppl 5): S39-43.

2 Montague DK, Jarow J, Broderick G, Dmochowski RR, Heaton JP, et al. Members of the Erectile Dysfunction Guideline Update Panel. American Urological Association guideline on the management of priapism. J Urol 2003; 170: 1318-24.

3 Burnett AL, Bivalacqua TJ. Priapism: current principles and practice. Urol Clin North Am 2007; 34: 631-42.

4 Broderick GA, Kadioglu A, Bivalacqua TJ, Ghanem $\mathrm{H}$, Nehra A, et al. Priapism: pathogenesis, epidemiology, and management. J Sex Med 2010; 7: 476-500.

5 Aliyu ZY, Kato GJ, Taylor J, Babadoko A, Mamman Al, et al. Sickle cell disease and pulmonary hypertension in Africa: a global perspective and review of epidemiology, pathophysiology, and management. Am J Hematol 2008; 83: 63-70.

6 Adeyoju AB, Olujohungbe AB, Morris J, Yardumian A, Bareford D, et al. Priapism in sickle-cell disease; incidence, risk factors and complications-an international multicentre study. BJU Int 2002; 90: 898-902.

7 Emond AM, Holman R, Hayes RJ, Serjeant GR. Priapism and impotence in homozygouse sickle cell disease. Arch Intern Med 1980; 140: 1434-7.

8 Mantadakis E, Cavender JD, Rogers ZR, Ewalt DH, Buchanan GR. Prevalence of priapism in children and adolescents with sickle cell anemais. J Pediatr Hematol Oncol 1999; 21: 518-22.

9 Lue TF. Priapism. In: Bryant WO, Bella AJ, Gracia MM, Lue TF. Emergencies in Urology New York: Springer Publishing; 2007. pp 301-12.

10 Hashmat AI, Rehman J. Priapism. In: Hashmat Al, Das S. The Penis Philadelphia, PA: Lea \& Febiger; 1993. pp 219-43.

11 Bruno D, Wigfall DR, Zimmerman SA, Rosoff PM, Wiener JS. Genitourinary complications of sickle cell disease. J Urol 2001; 166: 803-11.

12 Nelson JH, Winter CC. Priapism: evolution of management in 48 patients in a 22 year series. J Urol 1977; 117: 455-8.

13 Bennet N, Mulhall J. Sickle cell disease status and outcomes in African American men presenting with priapism. J Sex Med 2008; 5: 1244-50. 
14 Diggs LW, Ching RE. Pathology of sickle cell anemia. Southern Med J 1934; 27: 839-45.

15 Bivalacqua TJ, Burnett AL. Priapism. In: Graham SD, Glen JF. Glenn's Urologic Surgery. 7th ed Philadelphia, PA: Lippincott Williams \& Wilkins; 2010. pp 487-91.

16 Pierorazio PM, Bivalacqua TJ, Burnett A. Daily phosphodiesterase type- 5 inhibitor therapy as rescue for recurrent ischemic priapism after failed androgen ablation: a case report. J Androl 2011; 32: 371-4.

17 Gladwin MT, Sachdev V, Jison ML, Shizukuda Y, Plehn JF, et al. Pulmonary hypertension as a risk factor for death in patients with sickle cell disease. $N$ Engl J Med 2004; 350: 886-95.

18 Castro O, Hoque M, Brown BD. Pulmonary hypertension in sickle cell disease: cardiac catheterization results and survival. Blood 2003; 101: 1257-61.

19 Hinman F Jr. Priapism; reasons for failure of therapy. J Urol 1960; 83: 420-8.

20 Winter CC, McDowell G. Experience with 105 patients with priapism: update review of all aspects. J Urol 1988; 140: 980-3.

21 Francis RB, Johnson CS. Vascular occlusion in sickle cell disease: current concepts and unanswered questions. Blood 1991; 77: 1405.

22 Bivalacqua TJ, Burnett AL. Priapism: new concepts in pathophysiology and new treatment strategies. Curr Urol Rep 2006; 7: 497-502.

23 Bivalacqua TJ, Musicki B, Hsu LL, Gladwin MT, Burnett AL, et al. Establishment of transgenic sickle-cell mouse model to study the pathophysiology of priapism. J Sex Med 2009; 6: 2494-504.

24 Nolan VG, Wyszynski DF, Farrer LA, Steinberg MH. Hemolysis-associated priapism in sickle cell disease. Blood 2005; 106: 3264.

25 Abern MR, Levine LA. Ketoconazole and prednisone to prevent recurrent ischemic priapism. J Urol 2009; 182: 1401-6.

26 Yamashita N, Hisasue S, Kato R, Masumori N, Takahashi A, et al. Idiopathic stuttering priapism: recovery of detumescence mechanism with temporal use of antiandrogen. J Urol 2004; 63: 1182.

27 Steinberg J, Eyre RC. Management of recurrent priapism with epinephrine selfinjection and gonadotropin-releasing hormone analogue. J Urol 1995; 153: 152-3.

28 Costabile RA. Successful treatment of stutter priapism with an antiandrogen. Tech Urol 1998; 4: 167-8.

29 Dahm P, Rao DS, Donatucci CF. Antiandrogens in the treatment of priapism. Urology 2002; 59: 138.

30 Shamloul R, el Nashaar A. Idiopathic stuttering priapism treated successfully with low-dose ethinyl estradiol: a single case report. J Sex Med 2005; 2: 732-4.

31 Levine LA, Guss SP. Gonadotropin releasing hormone analogues in the treatment of sickle cell anemia associated priapism. J Urol 1993; 150: 475-7.

32 Bivalacqua TJ, Levey HR, Burnett AL. Priapism. In: Mulhall JP, Incrocci L, Goldstein I, Rosen R, editors. Cancer and Sexual Health, Current Clinical Urology New York: Springer Publishing; 2011. In Press.

33 van Driel MF, Joosten EA, Mensink HJ. Intracorporeal self-injection with epinephrine as treatment for idiopathic recurrent priapism. Eur Urol 1990; 17: 95-6.

34 Gbadoé AD, Atakouma Y, Kusiaku K, Assimadi JK. Management of sickle cell priapism with etilefrine. Arch Dis Child 2001; 85: 52-3.

35 Virag R, Bachir D, Lee K, Galacteros F. Preventive treatment of priapism in sickle cell disease with oral and self-administered intracavernous injection of etilefrine. Urology 1996; 47: 777-81.

36 Levine LA, Estrada CR, Latchamsetty KC. Idiopathic ischemic priapism. Preventing recurrence. Contemp Urol 2004; 16: 25-34.

37 Burnett AL. Priapism. In: Wein AJ, Kavoussi LR, Novick AW, Partin CA. CampbellWalsh Urology. 9th ed. Philadelphia, PA: Elsevier; 2007. pp 839-49.

38 Chinegwundoh FI, Anie KA. Treatments for priapism in boys and men with sickle cell disease. Cochrane Database Syst Rev 2004; 18: CD004198.

39 Serjeant GR, de Ceulaer K, Maude GH. Stilboestrol and stuttering priapism in homozygous sickle-cell disease. Lancet 1985; 2: 1274-6.

40 Rachid-Filho D, Cavalcanti AG, Favorito LA, Costa WS, Sampaio FJ. Treatment of recurrent priapism in sickle cell anemia with finasteride: a new approach. Urology 2009; 74: 1054-7.

41 Yuan J, DeSouza R, Westney OL, Wang R. Insights of priapism mechanism and rationale treatment for recurrent priapism. Asian J Androl 2008, 10: 88 .

42 DeCastro BJ, Costabile RA, McMann LP, Peterson AC. Oral ketoconazole fo prevention of postoperative penile erection: a placebo controlled, randomized, double-blind trial. J Urol 2008; 179: 1930-2.

43 Evans KC, Peterson AC, Ruiz HE, Costabile RA. Use of oral ketoconazole to prevent postoperative erections following penile surgery. Int J Impot Res 2004; 16: 346-9.

44 Bitran D, Miller SA, McQuade DB, Leipheimer RE, Sachs BD. Inhibition of sexual reflexes by lumbosacral injection of a GABA-B agonist in the male rat. Pharmacol Biochem Behav 1988; 31: 657-66.

45 Paredes RG, Agmo A. The GABA-B antagonist CGP 35348 inhibits the effects of baclofen on sexual behavior and motor coordination. Brain Res Bull 1995; 36: 495-7.

46 Vaidyanathan S, Watt JW, Singh G, Hughes PL, Selmi F, et al. Management of recurrent priapism in a cervical spinal cord injury patient with oral baclofen therapy. Spinal Cord 2004; 42: 134-5.

47 D'Aleo G, Rifici C, Kofler M, Saltuari L, Bramanti P. Favorable response to intrathecal, but not oral, baclofen of priapism in a patient with spinal cord injury. Spine 2009; 34: E127-9.

48 Denys $\mathrm{P}$, Mane M, Azouvi P, Chartier-Kastler E, Thiebaut JB, et al. Side effects of chronic intrathecal baclofen on erection and ejaculation in patients with spinal cord lesions. Arch Phys Med Rehabil 1998; 79: 494-6.
49 Rourke KF, Fischler AH, Jordan GH. Treatment of recurrent idiopathic priapism with oral baclofen. J Urol 2002; 168: 2552-3.

50 Cansever T, Civelek E, Sencer A, Karasu A, Turantan I. Intermittent priapism in degenerative lumbar spinal stenosis: case report. Turk Neurosurg 2007; 17: 260-3.

51 Perimenis P, Athanasopoulos A, Papathanasopoulos P, Barbalias G. Gabapentin in the management of recurrent, refractory, idiopathic priapism. Int J Impot Res 2004; 16: 84

52 Dong Q, Deng S, Wang R, Yuan J. In vitro and in vivo animal models in priapism research. J Sex Med 2011; 8: 347-59.

53 Daoud AS, Bataineh H, Otoom S, Abdul-Zahra E. The effect of vigabatrin, lamotrigine, and gabapentin on the fertility, weights, sex hormones, and biochemical profiles of male rats. Neuro Endocrinol Lett 2004; 25: 178.

54 Muneer A, Minhas S, Arya M, Ralph DJ. Stuttering priapism-a review of the therapeutic options. Int J Clin Pract 2008; 62: 621265

55 Gupta S, Salimpour P, Saenz de Tejada I, Daley J, Gholami S, et al. A possible mechanism for alteration of human erectile function by digoxin: inhibition of corpus cavernosum sodium/potassium adenosine triphosphatase activity. J Urol 1998; 159 1529-36.

56 Gupta S, Moreland RB, Munarriz R, Daley J, Goldstein I, et al. Possible role of $\mathrm{Na}^{+}$$\mathrm{K}^{+}$-ATPase in the regulation of human corpus cavernosum smooth muscle contractility by nitric oxide. Br J Pharmacol 1995; 116: 2201-6.

57 Sadeghi-Nejad H, Gupta S, Salimpour P, Daller M, Krane RJ, et al. Treatment of recurrent veno-occlusive priapism by digoxin. J Urol 1997; 157: 202.

58 Hugues FC, Julien D, Aufauvre B, Marche J. Clinical pharmacology of beta adrenergic agonists and antagonists. 2. Adrenergic medications; propranolol test, terbutaline test. Coeur Med Interne. 1973; 12: 417-23. French.

59 Hugues FC, Julien D, Aufauvre B, Marche J. Clinical pharmacology of terbutaline. I. Action on cardiac rate, systemic arterial pressures and ventilation. Therapie 14. French.1972; 27: 1001-14. French.

60 Ahmed AA, Marki A, Gaspar R, Vasas A, Mudawi MM, et al. Beta(2)-adrenergic activity of 6-methoxykaempferol-3-0-glucoside on rat uterus: in vitro and in silicostudies. Eur J Pharmacol 2011; 667: 348-54.

61 Ahmed I, Shaikh NA. Treatment of intermittent idiopathic priapism with oral terbutaline. Br J Urol 1997; 80: 340.

62 Lowe FC, Jarow JP. Placebo-controlled study of oral terbutaline and pseudoephedrine in the management of prostaglandin E1-induced prolonged erections. Urology 1993 43: $51-3$.

63 Shantha TR, Finnerty DP, Rodriquez AP. Treatment of persistent penile erection and priapism using terbutaline. J Urol 1989; 141: 1427-9.

64 Champion HC, Bivalacqua TJ, Takimoto E, Kass DA, Burnett AL. Phosphodiesterase$5 A$ dysregulation in penile erectile tissue is a mechanism of priapism. Proc Natl Acad Sci USA 2005; 102: 1661-6.

65 Burnett AL, Bivalacqua TJ, Champion HC, Musicki B. Long-term oral phosphodiesterase 5 inhibitor therapy alleviates recurrent priapism. Urology 2006; 67: 1043-8.

66 Bialecki ES, Bridges KR. Sildenafil relieves priapism in patients with sickle cell disease. Am J Med 2002; 113: 252.

67 Burnett AL, Bivalacqua TJ, Champion HC, Musicki B. Feasibility of the use of phosphodiesterase type 5 inhibitors in a pharmacologic prevention program for recurrent priapism. J Sex Med 2006; 3: 1077-84

68 Bivalacqua TJ, Musicki B, Champion HC, Burnett AL. Phosphodiesterase type 5 inhibitor therapy for priapism. In: Carson III CC, Kirby RS, Goldstein I, Wyllie MG, editors Textbook of Erectile Dysfunction. 2nd ed. New York: Informa HealthCare; 2009. pp 428-33.

69 McDonald M, Santucci RA. Successful management of stuttering priapism using home self injections of the alpha-agonist metaraminol. Int Braz J Urol 2004; 30 121-2.

70 Lue TF, Hellstrom WJ, McAninch JW, Tanagho EA. Priapism: a refined approach to diagnosis and treatment. J Urol 1986; 136: 104-8.

71 Ralph DJ, Pescatori ES, Brindley GS, Pryor JP. Intracavernosal phenylephrine for recurrent priapism: self administration by drug delivery implant. J Urol 2001; 165 1632-.

72 Teloken C, Ribeiro EP, Chammas M Jr, Teloken PE, Souto CA Intracavernosal etilefrine therapy for recurrent priapism: one decade follow-up. Urology 2005; 65: 1002.

73 Kanika ND, Tar M, Tong Y, Kuppam DS, Melman A, et al. The mechanism of opiorphininduced experimental priapism in rats involves activation of the polyamine synthetic pathway. Am J Physiol Cell Physiol 2009; 297: 916-27.

74 Dai Y, Zhang Y, Phatarpekar P, Mi T, Zhang H, et al. Adenosine signaling, priapism and novel therapies. J Sex Med 2009; 6 Suppl 3, 292-301.

75 Filippi S, Mancini M, Amerini S, Bartolini M, Natali A, et al. Functional adenosine receptors in human corpora cavernosa. Int J Androl 2000; 23: 210-7.

76 Sharifzadeh M, Zarrindast MR, Samini M. Effects of adenosine analogues on apomorphine-induced penile erection in rats. Gen Pharmacol 1995; 26 : 1785-90.

77 Lin CS, Lin G, Lue TF. Cyclic nucleotide signaling in cavernous smooth muscle. J Sex Med 2005; 2: 478-91.

78 Shalev M, Staerman F, Allain H, Lobel B, Saiag B. Stimulation of P2y purinoceptors induces, via nitric oxide production, endothelium-dependent relaxation of human isolated corpus cavernosum. J Urol 1999; 161: 955-9.

79 Wen J, Jiang X, Dai Y, Zhang Y, Tang Y, et al. Increased adenosine contributes to penile fibrosis, a dangerous feature of priapism, via $\mathrm{A} 2 \mathrm{~B}$ adenosine receptor signaling. FASEB J 2010; 24: 740-9. 